\title{
Analysis of Financing Mode of Small and Micro Enterprises Based on Internet Finance
}

\author{
Dong An ${ }^{1, ~ a, ~ J i a n f a n g ~} \mathrm{Li}^{2, \mathrm{~b}}$ and Man Liu ${ }^{3, \mathrm{c}}$ \\ ${ }^{1}$ College of Literature and Management, Hebei Agricultural University, Baoding 071001, Hebei Province, \\ China \\ ${ }^{2}$ College of Science and Technology Research, Hebei Agricultural University, Baoding 071001, Hebei \\ Province, China \\ ${ }^{3}$ College of Literature and Management, Hebei Agricultural University, Baoding 071001, Hebei Province, \\ China \\ a andong@126.com, ${ }^{\mathrm{b}}$ lijianfang@126.com, ${ }^{\mathrm{c}}$ liuman@126.com
}

Keywords: Internet finance; small and micro enterprises; financing model

\begin{abstract}
Recently, the rapid development of Internet technology produces the rapid development of Internet finance, which improves the financing efficiency of the block to carry out the new way of supply and demand of funds, break the financial monopoly and bring obvious innovation of the new model of financial services, and financial services in new areas in China. This paper mainly discusses difficulties and problems in the loan financing for small and micro enterprises encountered in the past mode and the past bank loans, and makes analysis on P2P, electronic business platform, and so on.
\end{abstract}

\section{Introduction}

Being a small and medium-sized enterprise in China is also a relatively important component, and it plays a very important role in China's economic development in the light of the current economic development. It is necessary to promote the development model of small and micro enterprises and Internet finance, and make use of the new development model to guarantee the improvement of China's overall economic level. Based on the above, we should strengthen the Internet finance and strengthen the theoretical research of small and micro enterprises, which will have a positive effect on the development of both. Internet finance has been a fast growing industry in recent years, taking advantage of both the financial industry and the technology of the Internet. Combined, so that it is own characteristics will be relatively obvious. The most important is that financial services realized under the use of large data. In the financial period of the Internet, the core asset of finance is data. However, the use of big data can achieve the objectives of credit risk analysis and high frequency trading. The entry service of the Internet is more inclined to the long tail theory, and the convenience and high efficiency of the service are more prominent. To the model of small and micro enterprises and Internet finance is a relatively important reform content in the current development. China's strategic development also has this demand. The innovation of financing mode has further promoted. China's small and micro enterprises play a more important role in the economic development of our country's people, so if we want to achieve a win-win goal for the financing model of small and micro enterprises and Internet finance, Must promote the innovation of financing mode of small and micro enterprises and internet finance. It is mainly that the support of the financing services of the Internet plays an important role in the small and micro enterprises, and the Internet financing revolves around the way in which the small and micro enterprises provide their own financial services. Moreover, the financing of small, micro-enterprises, and Internet finance also occupied a great advantage. In networked finance, small and micro enterprises the industry has effective access to the resources needed to finance its trading partners. The plight of small and micro enterprises in financing development is to rely on Internet finance to turn the corner. Compared with the previous models of indirect financing of commercial banks, 
direct financing of capital markets, and so on, the Internet financial financing model is convenient. According to the characteristics of small and micro enterprises, Internet finance will adopt different management methods, carry out differentiated management strategies, carry out innovation of financing products, and track customer satisfaction according to the characteristics of small and micro enterprises. To solve the problem of incorrect channel information in the data and the lack of information content, the loan platform. P2P network has no very exact circle of friends, but the amount of gold to be registered and loan on the Internet is small, and it will bused very well. There are many ways to identify the actual situation of the customers. The Internet information can reduce the cost of investment and financing, and improve the efficiency of investment and financing. In the rapid development, batches of Internet financing enterprises, which represented by Jingdong mall and Alibaba, have their profitability. The daily capital of medium and small enterprises can be satisfied. Financing information service providers are the Internet. They establish a large number of financing information databases as the basis, using online channels and offline salon forms to enhance the financing success rate of small and micro enterprises, and to solve the difficulty of information imprecise. The cost of doing business with each other has reduced. For example, JingDong Mall and Ali small loan designed the main elements of the product according to the characteristics of the customer, and adjusted the product elements differently according to the actual situation of each customer. According to the subdivision of customers, let small and micro enterprises have the option of autonomy and personality, and choose their own. There is no risk of capital trading and the phenomenon of $\mathrm{P} 2 \mathrm{P}$ platform running away from the need for financing and the financing product of financing quota.

\section{Peer-to-peer Lending.}

Peer-to-peer lending launched in April 2011, one of the earliest and best platforms for online lending in China. Peer-to-peer lending, the network lending platform represented by peer-to-peer lending, is the third network platform on the P2P basic mode. No matter which participant on the network can use this intermediary network platform to initiate, Use this network to communicate symmetric information, matching factors such as term, interest rate, risk, amount, etc. Moreover, according to the rules of the website to sign the relevant legal electronic contract to meet the needs of both parties and protects the interests of both sides.

In P2P network loan, it mainly involves three participants, I. e. Borrower, P2P network loan platform and lender. Their main behaviors and relationships are show in Table 1.

Table 1 main behaviors and relationships of participants in P2P network lending

\begin{tabular}{|c|c|c|c|}
\hline step & P2P network loan platform & borrower & lender \\
\hline First Steps & institute rules & $\begin{array}{c}\text { Submit credit review materials } \\
\text { to clarify the elements of loan } \\
\text { demand }\end{array}$ & $\begin{array}{c}\text { Register as a member of } \\
\text { the platform }\end{array}$ \\
\hline $\begin{array}{c}\text { The second } \\
\text { step }\end{array}$ & Audit credit, issue requirements & Waiting for funds docking & $\begin{array}{c}\text { Screening for borrowing } \\
\text { requirements that meet } \\
\text { your expectations, } \\
\text { returns and risks }\end{array}$ \\
\hline Step three & Determine the lending rate & $\begin{array}{c}\text { Signing of an electronic } \\
\text { contract }\end{array}$ & $\begin{array}{c}\text { Signing of an electronic } \\
\text { contract }\end{array}$ \\
\hline Step four & Receipt of funds & $\begin{array}{c}\text { To go through the formalities of } \\
\text { relaxation and pay the relevant } \\
\text { expenses }\end{array}$ & Investment success \\
\hline Step five & $\begin{array}{c}\text { Supervise repayment and payment of } \\
\text { all kinds of expenses to recover } \\
\text { defaulting items }\end{array}$ & $\begin{array}{c}\text { To repay by agreed installments } \\
\text { of once. }\end{array}$ & disinvestment \\
\hline
\end{tabular}

P2P network lending, represented by "everyone's loan", bypasses financial institutions such as banks, uses online lending platforms to realize financing and investment. It is a new loan relationship based on credit. It is smart and rapid in financing. The small amount is suitable for the 
financing needs of all kinds of small and micro enterprises.

\section{Appraise}

To sum up, the five representative financing channels of small and micro enterprises compared in four aspects: financing speed, capital cost, financing risk and value added effect, as shown in Table 2.

Table 2 comparison of five financing channels for small and micro enterprises

\begin{tabular}{|l|l|l|l|l|}
\hline $\begin{array}{l}\text { Financing } \\
\text { channel }\end{array}$ & $\begin{array}{l}\text { Financing } \\
\text { speed }\end{array}$ & $\begin{array}{l}\text { financial } \\
\text { expenses }\end{array}$ & Financing risk & $\begin{array}{l}\text { value-added } \\
\text { effect }\end{array}$ \\
\hline E loan online & $\star \star \star$ & $\star \star \star$ & $\star \star \star$ & $\star \star \star$ \\
\hline $\begin{array}{l}\text { peer-to-peer } \\
\text { lending }\end{array}$ & $\star \star \star \star$ & $\star \star \star \star$ & $\star \star \star \star$ & $\star \star \star$ \\
\hline Ali small cargo & $\star \star \star \star \star$ & $\star \star$ & $\star \star$ & $\star \star$ \\
\hline Roll call time & $\star \star \star$ & $\star \star$ & $\star \star \star$ & $\star \star \star \star$ \\
\hline
\end{tabular}

Small and micro enterprises can choose their own financing channels according to the different characteristics of financing channels with the help of Internet finance.

\subsection{Practical significance of innovative financing Mode}

To promote the national strategic demand and policy support, the innovation of Internet financial model is the important way to achieve win-win situation in the financing of small and micro enterprises. On the one hand, the stable development of small and micro enterprises be separated from the financing support of the Internet; on the other hand, the financial services of the Internet need to be developed according to the small and micro enterprises, so long as this can achieve financial innovation in the end. Although small and micro enterprises are not yet very strong, they are still the main factors that can promote the economic development of the people, play a vital role in promoting innovation and flourishing market and expanding employment, and ensure that small and micro enterprises. Capital can directly link to the overall economic and social development, so it plays a very important role.

The financing mode of small and micro-enterprises and the innovation of internet finance paid much attention to by national financial policy. In recent years, with the financial reform work, fiscal policy has also increased support for this new model, indicating that the state is paying attention to the Internet amount can effectively solve the financing difficulties of small and micro enterprises.

\subsection{The advantages of this innovation model}

All along, the difficult problem of financing is an important factor restricting the development of small and micro enterprises. In recent years, the debt of small and micro enterprises is getting more and more serious, their financing demand is more and more strong, but the difficulty of financing is still rising, financing also appeared the characteristics of short cycle, urgent demand and so on.

The entry of Internet finance has brought about a change in financing difficulties for small and micro enterprises. Compared with previous financing, the financial model of the Internet has the following characteristics: first, universality. Small and micro enterprises can use Internet finance to obtain partners more easily, and under the Internet service, the threshold of financing for small and micro enterprises has also been lowered; third, the Internet is based on the different situation of small and micro enterprises. Practicing a different kind of help $=$ helping and Services. According to different users, to provide different systems, so that small and micro-enterprises can find their own financing products and solutions. The Problems Existing in the Network Financing of Small Micro enterprises in China

\subsection{Small scale of network financing}

According to the report issued by China's Electronic Commerce Center on the data of China's 
e-commerce market in the first half of 2010, we can see that by July of 2010, the total amount of transactions in China's e-commerce market amounted to 3.05 trillion Yuan. However, in the first half of 2010, the size of the online financing market was only 5.9 billion Yuan, down 19 percent from 8 billion in the first half of 2009, according to data on the size of the financing market provided by B2B. There is no way to satisfy the huge amount of financing needed by small and micro enterprises, if we want to solve it completely. When it comes to financing difficulties for small and micro enterprises, network financing must work with financial institutions such as banks and e-commerce enterprises. At the same time, because most of the enterprises that provide network financing adopt a membership system, on this basis, yes, the target range of network financing applications has also become smaller.

\subsection{Financing channels are too narrow}

The current way of Internet financing in China based on the basic mode of the third party financing intermediary. The third party platform provides the information platform for both sides. The small and micro enterprises have put forward the application for financing. However, because the demand for small and micro enterprises is very large, the current financing channels have no way to solve the small micro.

\subsection{Related laws and regulations and imperfect Financial Supervision}

At present, China still does not have laws and regulations on the activities related to network financing, and the network financing lack legal protection. Therefore, the relevant departments also have no way to regulate the activities of network financing exactly. This allows network-financing activities into the regulatory "vacuum area." Because this is a new way of financing, it is the Internet as a medium, the use of the Internet, so there will be a lot of uncertainty in the development of business. However, since China is current law does not have the means to adapt to the development of online financing activities, when this uncertainty becomes controversial, it is very important to rely on the existing laws and regulations. It is difficult to solve this dispute. In addition, as more and more non-financial and financial institutions are involved in the business of Internet financing, it is bound to strengthen the difficulty of supervising network financing.

\section{Countermeasures and Suggestions on Perfecting the Network Financing of Small and Micro Enterprises in China}

The unique advantages of network financing have successfully passed the verification of Ali's small loans. He will certainly be one of the important development businesses of the financial industry in the future. However, the emergence of network financing in China is relatively late, and there will still be many problems. This makes the network financing in China has not carried out on a larger scale. In order to promote the development of network financing in China, improve the network financing system. Be able to start with banks, businesses, governments, and so on.

\subsection{Government side}

(1) Develop laws and regulations related to network financing. At present, the management of financing activities in China is lack of specific laws and regulations, network-financing activities on the name is not correct, so we must improve the relevant legal norms. Network financing if the head is really to do according to the law, it is possible to develop all the time.

(2) To perfect the supervision system of network, we must strengthen the supervision of network in order to avoid the problems in supervision of network financing. When different types of regulators encounter cross-regulation, they must strengthen cooperation, share resources, adopt the same regulatory standards, and agree as much as possible.

\subsection{Banking side}

(1) The network financing credit implemented by commercial banks not only simplifies the process of loans, but also reduces the cost of bank loans and is very well integrated into the normal 
business.

(2) Value talented person, overcome the financing technical problem of network. Network financing brings many benefits to banks, at the same time; it also brings a variety of risks related to technology. Network financing is inseparable from the application and technology of network technology. Therefore, banks should introduce professional technicians, especially to strengthen the training of people with financial knowledge. At the same time, we should increase the network security and research; improve the emergency mechanism to ensure that the network financing system can used normally when there are problems.

(3) To develop new channels of network financing, the current Chinese network financing based on the mode of bank lending. This simple network-financing channel simply has no way to meet the huge financing requirements of small and micro enterprises. Therefore, commercial banks should develop new channels, such as innovation of financial products, but also transform the concept of management.

Small and micro-enterprises have to improve their comprehensive strength. As long as small and micro enterprises can improve their ability to raise funds by taking on their own examples, at the same time, they can improve the corporate governance structure, enhance the financial transparency of the company, and strengthen management and supervision. Only in this way can better meet the financing requirements of loans, can better wait for loans. Strengthen the concept of credibility and strengthen cooperation with banks. Small and micro enterprises should always strengthen the concept of credit, pay their debts on time, reduce their bad credit behavior, and when they encounter problems, they should take the initiative to negotiate with banks and strengthen cooperation with banks.

\section{Conclusion}

Domestic and foreign small and micro enterprises have encountered great problems in financing, which caused by external and internal reasons. For internal reasons: the majority of small and micro enterprises have small scale assets, fixed funds are not sufficient, financial aspects of the system is not perfect, the financial information is not true and transparent enough, the human resources are also very short, the management level is also low, and so on.

However, with the sustainable development of Internet finance in China, the development of network financing has also accelerated the pace of development. As a combination of micro-credit and Internet, network financing has solved the difficulties of many small and micro enterprises in China. The success of Ali small loan shows that network loan is a new financing form suitable for China's national conditions.

\section{References}

[1] Lou W long. To guide bank resources to play an active role in supporting the growth of small and micro enterprises-taking Beijing banking as an example [J]. A banker. (2012C 04)

[2] Zhu Q. A brief Analysis on the New financing Mode of Zhejiang small and Micro Enterprises [J]. Modern commerce. (2012-06)

[3] Mo Yi - h. A review of the theory and practice of peer - to - peer network lending at home and abroad is reviewed in this paper. Financial Theory and Practice. 2011 ( 12 )

[4] Ye Bin. Bank to Business Network financing Mode-A New Exploration of SME financing Mode [J]. Journal of Beijing University of posts and Telecommunications (Social Science Edition). 2011 / 05)

[5] L X. Research on Mutual guarantee financing Model of small and Medium-sized Enterprises-taking Y eng City, Shandong Province as an example [J]. Productivity research. 2011 / 08)

[6] Wu Xiao g. Talking about the risk control of commercial bank's network financing business [J]. 
new finance. 2011 (07)

[7] Chen Q. Network loan and its risk Analysis for small and Medium-sized Enterprises [J]. Trade in China. (2011 / 15)

[8] Liu Q. Risk Analysis and Control of supply chain Finance [J]. Time finance. 2011 / 14)

[9] Chen J jun. P2P Network Lending: problems and Countermeasures in Financial Innovation [J]. Scientific and technological information 2011 / 13)

[10] Wu W d. Analysis on the Development Countermeasures of Network financing for small and Medium-sized Enterprises in China [J]. Modern commerce and industry. 2011 / 09)

[11] Yu Wei, Qin Ying. Research on the financing Mode of small and Micro Enterprises in the context of Internet Finance [J]. Enterprise economy. 2014 / 12)

[12] Li Chao, L J w. Research on Small Micro - enterprise Financing Strategy Based on Internet Finance Modern Management Science. 2015 (01) 